\title{
Kadar Malondialdehid tikus model Sindroma Ovarium Polikistik dengan daun kelor (Moringa oleifera)
}

\author{
Lisa Purbawaning Wulandari*1, Budi Santoso ${ }^{2}$, Bambang Purwanto ${ }^{3}$ \\ ${ }^{1}$ Mahasiswa Magister Ilmu Kesehatan Reproduksi, Fakultas Kedokteran, Universitas \\ Airlangga Surabaya, Jalan Mayjend Prof. Dr. Moestopo No. 6 - 8, Airlangga, Gubeng, \\ Surabaya, Jawa Timur 60285 Indonesia, Telp (031) 5501078 \\ ${ }^{2}$ Departemen Obstetri dan Ginekologi, Fakultas Kedokteran, Universitas Airlangga, RSUD \\ Dr. Soetomo \\ ${ }^{3}$ Departemen Fisiologi, Fakultas Kedokteran, Universitas Airlangga \\ e-mail: *1 lisawuland@gmail.com, ${ }^{2}$ wadek2@fk.unair.ac.id, ${ }^{3}$ bpaifo@gmail.com
}

\begin{abstract}
Abstrak
Sindroma Ovarium Polikistik (SOPK) merupakan endokrinopati paling umum pada perempuan yang sering dikaitkan dengan resistensi insulin, hyperandrogenemia, peradangan kronis, dan oxydative stress. Tingkat oxydative stress pada SOPK diamati secara signifikan berkorelasi dengan obesitas, bahkan ditemukan memainkan peran penting dalam patogenesis kanker. Antioksidan adalah substansi yang diperlukan tubuh untuk menetralisir radikal bebas, penggunaan kelor (Moringa Oleifera) sebagai antioksidan perlu diteliti sebagai alternatif pengobatan terhadap oxydative stress pada SOPK dengan resistensi insulin. Penelitian eksperimen ini menggunakan tikus Rattus norvegicus strain wistar betina berusia 3 bulan dengan berat 100-130 gram dibagi menjadi 4 kelompok $(n=8)$. Tikus model SOPK diberikan injeksi testosteron propionat sebesar $1 \mathrm{mg} / 100 \mathrm{grBB}$ secara intramuskular selama 28 hari, selanjutnya diberikan ekstrak daun kelor (Moringa Oleifera) dengan dosis 250 dan $500 \mathrm{mg} / \mathrm{KgBB}$ selama 14 hari. Kemudian dilakukan pengukuran berat badan dan pemeriksaan kadar Malondialdehid (MDA) dalam darah. Hasil penelitian menunjukan bahwa kadar MDA pada kelompok kontrol SOPK naik secara signifikan $(p<0.05)$ dibandingkan dengan kontrol normal. Pemberian ekstrak daun kelor (Moringa Oleifera) $500 \mathrm{mg} / \mathrm{KgBB}$ menunjukan penurunan yang signifikan $(p<0.05)$ terhadap kadar MDA dibanding kelompok kontrol SOPK. Pemberian ekstrak daun kelor (Moringa Oleifera) sebagai antioksidan terbukti dapat menurunkan kadar MDA tikus betina model SOPK dengan resistensi insulin.
\end{abstract}

Kata kunci: Kadar Malondialdehid, ekstrak daun kelor (Moringa Oleifera), Sindroma Ovarium Polikistik 
Polycystic Ovary Syndrome (PCOS) is the most common endocrinopathy in women often associated with insulin resistance, hyperandrogenemia, chronic inflammation, and oxydative stress. The rate of oxydative stress on SOPK observed significantly correlated with obesity, was even found to play an important role in the pathogenesis of cancer. Antioxidants are substances that the body needs to neutralize free radicals, the use of Moringa Oleifera as an antioxidant should be investigated as an alternative treatment for oxydative stress in PCOS with insulin resistance. This experimental study used a 3-month-old female Rattus norvegicus strain of wistar strain weighing 100-130 grams divided into 4 groups $(n=8)$. PCOS model rat were given intramuscularly $1 \mathrm{mg} / 100 \mathrm{grBW}$ injections for 28 days, then Moringa Oleifera extract was given with dose 250 and $500 \mathrm{mg} / \mathrm{KgBW}$ for 14 days. Then performed weight measurement and examination of levels of Malondialdehyde (MDA) in the blood. The results showed that MDA levels in the PCOS control group increased significantly $(p<0.05)$ compared with normal controls. Moringa leaf extract (Moringa Oleifera) $500 \mathrm{mg} / \mathrm{KgBB}$ showed significant decrease $(p<0.05)$ to MDA level compared to control group of PCOS. Provision of Moringa leaf extract (Moringa Oleifera) as an antioxidant proven to decrease levels of MDA female rat PCOS model with insulin resistance.

Keywords: Malondialdehid levels, Moringa Oleifera leaf extract, Polycystic Ovary Syndrome 


\section{PENDAHULUAN}

Sindroma Ovarium Polikistik (SOPK) merupakan endokrinopati paling umum pada perempuan, menyerang perempuan pada usia reproduksi $(5-10 \%)$, mempunyai resistensi terhadap insulin $(50-70 \%)$, hiperplasi endometrium (35\%), dapat terjadi kanker endometrium ( 3 - 5 kali lipat), mengalami recurrent pregnancy loss (36-56\%) (Homburg, 2008). Prevalensi gambaran klinis SOPK sangat beragam. Franks (1989) dalam penelitiannya melaporkan dari 300 wanita SOPK mengalami amenore (52\%), oligomenore (28\%), hirsutisme (64\%), mengalami obesitas (35\%), dengan acne (27\%), alopecia (3\%), dengan tanda-tanda akantosis nigrikan (kurang dari 1\%), dan mengalami infertilitas (42\%) (Balen et al., 2005).

Definisi SOPK mencakup beberapa kriteria klinis, biokimia serta morfologi ovarium. Wanita dengan siklus regular dan hiperandrogenisme diakui bisa menjadi bagian sindroma ini. SOPK dapat didiagnosis jika mempunyai dua dari tiga kriteria berikut ini ; ovarium polikistik, oligo/anovulasi atau bukti klinis/biokimia dari hiperandrogenisme (Fauser et al., 2012). SOPK telah dianggap sebagai penyakit sistemik kronis bukan penyakit lokal yang sederhana, dan itu sering dikaitkan dengan resistensi insulin (IR), hyperandrogenemia, peradangan kronis, dan oxydative stress (OS), meskipun patogenesis belum didefinisikan dengan baik. Reactive Oxygen Species (ROS) dapat menginduksi pelepasan faktor-faktor inflamasi dan respon inflamasi melalui aktivasi nuclear factor-kB (NF-kB), activated protein-1 (AP-1) dan hypoxia-inducible factor-1 (HIF1)(Touyz, 2005). Selanjutnya oxydative stress (OS) bersama inflamasi dapat menginduksi resistensi insulin melalui post insulin receptor signaling pathway, insulin receptor substrate 1 phosphatidyl inositol 3 kinase-protein kinase $B$ (IRSI-PI3K-PKB/Akt) pathway.

Resistensi insulin mengarah pada kompensasi hiperinsulinemia, meningkatkan frekuensi GnRH dan sekresi pulsasi LH sehingga produksi androgen di ovarium meningkat. Insulin dan IGF-1 secara tidak langsung juga dapat meningkatkan kadar androgen dengan menurunkan produksi SHBG (Sex Hormone Binding Globulin) di hati dan menekan sintesis IGFBP-1 (Insuline Like Growth Factor Binding Protein-1) secara langsung, cepat, dan lengkap baik di hati dan ovarium sehingga level IGF-I, IGF-II, dan testosteron bebas meningkat. Insulin dan Insulin-Like Growth Factor-1 (IGF-I) bertanggung jawab mengganggu ovulasi. (Rojas et al., 2014).

SOPK adalah kelainan endokrin, patofisiologinya masih belum diketahui secara jelas. Kontributor genetik dan lingkungan terhadap gangguan hormonal bergabung dengan kontributor lain seperti obesitas, disfungsi ovarium, dan abnormalitas hipofisis yang berkontributor kuat terhadap etiologi SOPK (dideteksi pada sekitar 60-80\% kasus). Resistensi insulin juga merupakan kontributor SOPK dan terdeteksi sekitar $50-80 \%$ pada wanita dengan SOPK, terutama pada pasien SOPK yang memiliki tingkat keparahan lebih tinggi dan obesitas.

Wanita yang kurus dan wanita dengan SOPK derajat ringan tampaknya mengalami resistensi insulin dan hiperinsulinemia yang tidak berat. Resistensi insulin berkontribusi terhadap gambaran metabolik tetapi juga terhadap gambaran reproduksi melalui hiperandrogen, hirsutisme, infertilitas, dan komplikasi kehamilan. Obesitas juga memperburuk faktor peningkatan risiko SOPK terkait gangguan toleransi glukosa, diabetes melitus tipe 2, dan penyakit kardiovaskuler, sedangkan obesitas juga mempengaruhi gambaran psikologis SOPK (Valkenburg et al., 2008, Teede et al., 2011).

Kelainan utama yang terlibat dalam patofisiologi SOPK (Homburg, 2003), yaitu; 1) Produksi androgen ovarium yang berlebih

Jumlah pembentukan androgen ovarium yang berlebihan adalah penyebab utama dari SOPK, hampir semua mekanisme enzimatik pada SOPK yang mengakibatkan produksi androgen meningkat. Peningkatan insulin dan LH, baik secara sendirian ataupun bersamaan akan meningkatkan produksi androgen. Abnormalitas steroidogenik andrenal umum didapatkan pada wanita dengan hiperandrogen termasuk pada SOPK. Pasien dengan SOPK menunjukkan terutama peningkatan produksi androgen dari ovarium, peningkatan kadar androgen adrenal terutama dehydroepiandrosterone sulfate (DHEAS) terdapat pada 20-30\% pasien SOPK. Androgen adrenal mempunyai 
kontribusi pada phenotype SOPK, yaitu hirsutisme. Secara keseluruhan penyebab dari peningkatan kadar androgen adrenal yang berlebihan pada SOPK belum jelas diketahui. Peningkatan kadar androgen adrenal pada SOPK tampaknya ditentukan oleh faktor ekstra adrenal seperti steroid ovarium dan insulin. Efek utama dari androgen ekstra adrenal dan insulin adalah meningkatkan aktifitas sulfotransferase, menghambat konversi DHEA menjadi DHEAS (Rusnasari, 2005).

Jumlah androgen yang berlebih mengakibatkan gangguan folikulogenesis sehingga mengakibatkan gangguan menstruasi dan pengembangan beberapa kista di ovarium. Androgen (testosteron) mengakibatkan menurunnya jumlah dan efektivitas protein pengangkut glukosa, khususnya glucose transporter type 4 (GLUT-4) yang bertanggung jawab terhadap pengangkutan glukosa di otot dan lemak sehingga terjadi resistensi insulin. Testosteron menyebabkan peningkatan asam lemak bebas dengan cara memfasilitasi lipolisis dan pemecahan lemak abdomen. Peningkatan androgen dan asam lemak bebas akan menghambat ekskresi insulin di hepar dan pengangkutan glukosa di otot, serta akhirnya menyebabkan hiperinsulinemia dan resistensi insulin (Marshall, 2001, Mukherjee and Maitra, 2010).

2) Morfologi ovarium yang abnormal

Morfologi ovarium polikistik merupakan gambaran utama dari SOPK yang didefinisikan sebagai menstruasi tidak teratur dan hiperandrogenisme. Keberadaan morfologi ovarium polikistik tidak cukup untuk mendiagnosis SOPK dan dapat terlihat pada wanita normal (Bostanc1 et al., 2012). Pada penderita SOPK folikel tampak seperti kantung berisi cairan yang terlihat di dalam ovarium. Morfologi ultrasonografi dari ovarium polikistik ditandai dengan adanya 12 atau lebih folikel ovarium yang ukurannya antara 2-9 $\mathrm{mm}$, mempunyai rerata atresia yang lambat dan sensitif terhadap FSH eksogen. Folikel ini disebut sebagai kista. Mereka diatur secara perifer di dalam ovarium pada pasien SOPK.

Pembesaran volume stroma hampir selalu ada, menyebabkan penambahan volume total dari ovarium >10cc. Penyebab kelainan morfologi ini diduga karena adanya androgen yang berlebihan. Androgen yang berlebihan juga dapat mempercepat proses pertumbuhan folikel primer sampai dengan stadium folikel per-antral dan small antral dibandingkan dengan ovarium yang normal. Kombinasi dari beberapa faktor yang menyebabkan perubahan pada morfologi ovarium dan karakteristik pada ovarium polikistik antara lain adalah kelebihan beberapa faktor yang menghambat kerja dari FSH endogen (seperti follistatin, epidermal growth factor, dll) dan kelebihan factor antiapoptotic (BCL-2) yang dapat memperlambat turn over dari folikel yang terhambat ini. (Tan, 2011).

3) Kadar serum LH yang berlebihan

Wanita dengan siklus menstruasi normal akan berbeda dengan wanita SOPK. Pada wanita dengan SOPK akan menunjukkan sekresi LH yang tinggi dan sekresi FSH yang rendah secara konstan. Peningkatan rasio LH/FSH 2-3:1 secara laboratoris dipakai untuk menunjukkan sekresi gonadotropin yang meningkat. Peningkatan serum LH pada wanita dengan SOPK antara 30-90\% (Rusnasari, 2005).

Salah satu yang mendasari regulasi abnormal GnRH pada SOPK sampai saat ini tetap belum jelas. Beberapa teori menyatakan bahwa ada perubahan input sistem neuronal GnRH yang disebabkan oleh insulin, IGFs, dan steroid sex selama fase pubertas yang akan menginduksi terjadinya disregulasi GnRH. Peningkatan kadar estrone yang kronik, aromatisasi estrogen yang lemah secara perifer dari androstenedion pada SOPK diduga pula menghambat sensitivitas GnRH secara langsung sintesis gonadotropin melalui reseptor GnRH (Rusnasari, 2005).

Kadar serum LH yang berlebihan didapatkan lebih kurang 40-50\% wanita dengan SOPK yang dideteksi pada satu kali pemeriksaan sampel darah. Kadar LH yang tinggi lebih banyak terdapat pada wanita dengan berat badan yang kurus dibandingkan dengan wanita yang obesitas, walaupun kadar serum FSH dalam batas normal, tetapi didapatkan penghambatan intrinsik pada kerja FSH. Kadar prolaktin mungkin sedikit meningkat.

4) Hiperinsulinemia 
Hiperinsulinemia yang disebabkan oleh resistensi insulin terjadi pada wanita dengan SOPK dan obesitas sentral (lebih kurang $80 \%$ ), hiperinsulinemia ini juga terjadi pada wanita dengan SOPK yang berbadan kurus (lebih kurang 30-40\%). Hal ini disebabkan oleh kelainan pada insulin post-receptor dimana seharusnya yang bekerja fosforilasi tirosin tetapi yang terjadi adalah fosforilasi serin, hal ini memberi efek pada transport glukosa yang masuk ke dalam sel otot ataupun lemak. Pada keadaan resistensi insulin terjadi gangguan sinyal transduksi insulin yang melibatkan dua jalur utama yaitu p38 Mitogen Activated Protein Kinase (MAPK) dan Phosphatidilinositol 3 Kinase (PI3K) (Kusumastuty and Ratnawati, 2013).

Resistensi insulin secara bermakna di eksaserbasi oleh obesitas dan merupakan faktor utama dalam patogenesis anovulasi dan hiperandrogenisme. Kelainan fungsi dari sel beta pankreas juga ditemukan pada SOPK.

Keadaan hiperinsulinemia berakibat pada timbulnya hiperandrogen melalui beberapa mekanisme, pada hati akan berakibat menurunkan produksi SHBG serta penurunan IGFBP-1. Penurunan SHBG akan meningkatkan estradiol serta testosteron bebas (dalam bentuk aktif) dalam darah, sedangkan penurunan IGFBP-1 berakibat meningkatkan bioavalibitas IGF-1 di sel teka, hal ini sangat berperan dalam proses maturasi folikel serta steroidogenesis. Bersama dengan IGF-2 yang dihasilkan di sel teka maka IGF-1 akan merangsang ovarium untuk memproduksi androgen melalui rangsangan pada reseptor IGF-1, hal ini berakibat pada peningkatan androstenedion dan testosteron (Slowey, 2001, Balen et al., 2005).

Penelitian terdahulu telah mengungkapkan bahwa tingkat OS meningkat secara signifikan pada pasien dengan SOPK dibandingkan dengan normal, saat status oksidatif dievaluasi oleh penanda sirkulasi, seperti malondialdehid (MDA), superoksida dismutase (SOD), dan glutathione peroxidase (GPx) (Zuo et al., 2015). Produk reaksi peroksidasi lipid telah banyak digunakan sebagai biomarker untuk OS. MDA, yang dihasilkan selama dekomposisi asam lemak tak jenuh ganda, adalah salah satu produk akhir yang stabil dari peroksidasi lipid yang dapat berfungsi sebagai biomarker yang baik.
Penelitian yang dilakukan oleh Sabuncu et al (2001), Zhang et al (2008) dan Kuscu et al (2009) menunjukan tingkat kadar serum MDA yang meningkat secara signifikan pada pasien SOPK dibandingkan dengan non SOPK (Yeon Lee et al., 2010).

Tingkat OS juga diamati secara signifikan berkorelasi dengan obesitas, resistensi insulin, hyperandrogenemia, dan peradangan kronis (Zuo et al., 2015). Lebih dari itu, OS dalam SOPK, ditemukan memainkan peran penting dalam patogenesis kanker. Reactive Oxygen Species (ROS) bisa menyebabkan perubahan genetik dengan menyerang DNA, menyebabkan kerusakan DNA, seperti DNA strand breaks, point mutations, aberrant DNA cross-linking, dan DNA-protein cross-linking (Ziech et al., 2011).

Oxydative stress sering disebut sebagai ketidakseimbangan antara oksidan dan antioksidan. Ketika ketidakseimbangan menguntungkan oksidan, maka pembentukan Reactive Oxygen Species (ROS) yang berlebihan membahayakan tubuh kita dengan berbagai cara. ROS adalah radikal bebas dengan pusat oksigen. Elektron yang tidak berpasangan di kulit terluar adalah konfigurasi yang sangat tidak stabil, dan radikal bebas dengan cepat bereaksi dengan molekul atau radikal lain untuk mencapai konfigurasi yang stabil dari pasangan elektron pada kulit terluarnya (Agarwal et al., 2005). Dengan kata lain, selsel reproduksi dan jaringan akan tetap stabil hanya ketika status antioksidan dan oksidan seimbang.

Enzim Superoxide Dismutase (SOD) yang terdapat di mitokondria dan sitosol, Glutathione Peroxidase (GPX), Glutathione reductase, dan catalase merupakan system pertahanan yang melengkapi untuk menangkal serangan radikal bebas atau oksidan sehingga dapat membatasi kerusakan yang diakibatkan oleh radikal bebas (Jackson, 2005). Sistem pertahanan lain di dalam tubuh selain enzim untuk menangkal serangan radikal bebas adalah antioksidan yang berupa Selain itu terdapat juga sistem pertahanan mikronutrien yaitu Bkaroten, vitamin $\mathrm{C}$ dan vitamin E. Sistem pertahanan ini bekerja dengan beberapa cara antara lain berinteraksi langsung dengan radikal bebas, oksidan, atau oksigen tunggal, mencegah pembentukan senyawa oksigen 
reaktif, atau mengubah senyawa reaktif menjadi kurang reaktif (Winarsi, 2005). Namun dalam keadaan tertentu, produksi radikal bebas atau senyawa oksigen reaktif melebihi sistem pertahanan tubuh, kondisi yang disebut sebagai stres oksidatif (Agarwal et al., 2005).

Pada kondisi stres oksidatif, imbangan normal antara produksi radikal bebas atau senyawa oksigen reaktif dengan kemampuan antioksidan alami tubuh untuk mengeliminasinya mengalami gangguan sehingga menggoyahkan rantai reduksioksidasi normal, sehingga menyebabkan kerusakan oksidatif jaringan. Kerusakan jaringan ini juga tergantung pada beberapa faktor, antara lain: target molekuler, tingkat stres yang terjadi, mekanisme yang terlibat, serta waktu dan sifat alami dari sistem yang diserang (Winarsi, 2005).

Penelitian yang ekstensif dengan menggunakan sistem model dan dengan material biologis in vitro, secara jelas menunjukkan bahwa radikal bebas dapat menimbulkan perubahan kimia dan kerusakan terhadap protein, lemak, karbohidrat, dan nukleotida. Bila radikal bebas diproduksi in vivo, atau in vitro di dalam sel melebihi mekanisme pertahanan normal, maka akan terjadi berbagai gangguan metabolik dan seluler. Jika posisi radikal bebas yang terbentuk dekat dengan DNA, maka bisa menyebabkan perubahan struktur DNA sehingga bisa terjadi mutasi atau sitotoksisitas.

Radikal bebas juga bisa bereaksi dengan nukleotida sehingga menyebabkan perubahan yang signifikan pada komponen biologi sel. Bila radikal bebas merusak grup thiol maka akan terjadi perubahan aktivitas enzim. Radikal bebas dapat merusak sel dengan cara merusak membran sel tersebut. Kerusakan pada membran sel ini dapat terjadi dengan cara: (a) radikal bebas berikatan secara kovalen dengan enzim dan/atau reseptor yang berada di membran sel, sehingga merubah aktivitas komponenkomponen yang terdapat pada membran sel tersebut; (b) radikal bebas berikatan secara kovalen dengan komponen membran sel, sehingga merubah struktur membran dan mengakibatkan perubahan fungsi membran dan/atau mengubah karakter membran menjadi seperti antigen; (c) radikal bebas mengganggu sistem transport membran sel melalui ikatan kovalen, mengoksidasi kelompok thiol, atau dengan merubah asam lemak polyunsaturated; (d) radikal bebas menginisiasi peroksidasi lipid secara langsung terhadap asam lemak polyunsaturated dinding sel. Radikal bebas akan menyebabkan terjadinya peroksidasi lipid membran sel. Peroksida-peroksida lipid akan terbentuk dalam rantai yang makin panjang dan dapat merusak organisasi membran sel (Sikka et al., 1995). Peroksidasi ini akan mempengaruhi fluiditas membran, cross-linking membran, serta struktur dan fungsi membran (Powers and Jackson, 2008).

Mekanisme kerusakan sel atau jaringan akibat serangan radikal bebas yang paling awal diketahui dan terbanyak diteliti adalah peroksidasi lipid. Peroksidasi lipid paling banyak terjadi di membran sel, terutama asam lemak tidak jenuh yang merupakan komponen penting penyusun membran sel. Pengukuran tingkat peroksidasi lipid diukur dengan mengukur produk akhirnya, yaitu malondialdehyde (MDA), yang merupakan produk oksidasi asam lemak tidak jenuh dan yang bersifat toksik terhadap sel. Pengukuran kadar MDA merupakan pengukuran aktivitas radikal bebas secara tidak langsung sebagai indikator stres oksidatif. Pengukuran ini dilakukan dengan tes Thiobarbituric Acid Reactive Substances (TBARS test) (Powers and Jackson, 2008).

Antioksidan adalah substansi yang diperlukan tubuh untuk menetralisir radikal bebas dan mencegah kerusakan yang ditimbulkan oleh radikal bebas terhadap sel normal, protein, lemak. Antioksidan menstabilkan radikal bebas dengan melengkapi kekurangan elektron yang dimiliki radikal bebas, dan menghambat terjadinya reaksi berantai dari pembentukan radikal bebas yang dapat menimbulkan OS. Sejumlah penelitian pada tanaman melaporkan bahwa banyak tanaman yang mengandung antioksidan dalam jumlah besar. Efek antioksidan terutama disebabkan karena adanya senyawa fenol seperti flavonoid dan asam fenolat. Biasanya senyawa-senyawa yang memiliki aktifitas antioksidan adalah senyawa fenol yang mempunyai gugus hidroksi yang 
tersubstitusi pada posisi orto dan para terhadap gugus $-\mathrm{OH}$ dan $-\mathrm{OR}$.

Pencarian tumbuh-tumbuhan yang mempunyai kemampuan potensial sebagai terapi pencegahan dan secara keilmuan terbukti bisa digunakan untuk alternatif pengobatan sangat dibutuhkan. (Moringa Oleifera) (drumstick tree, horse-radish tree, miracle tree) yang di Indonesia dikenal dengan nama kelor merupakan salah satu tanaman yng mengandung antioksidan.

Tanaman kelor yang dalam bahasa latin disebut dengan Moringa oleifera awalnya banyak tumbuh di India, tetapi saat ini banyak ditemukan di daerah beriklim tropis (Grubben, 2004). Pada beberapa negara kelor (Moringa oleifera) dikenal dengan nama benzolive, drumstick tree, kelor, marango, mlonge, mulangay, nebeday, saijhan, dan sajna (Fahey, 2005).

Tanaman kelor memiliki klasifikasi sebagai berikut; Kingdom: Plantae (Tumbuhan); Subkingdom: Tracheobionta (Tumbuhan berpembuluh); Super Divisi: Spermatophyta (Menghasilkan biji); Divisi: Magnoliophyta (Tumbuhan berbunga); Kelas: Magnoliopsida (berkeping dua/dikotil); Sub Kelas: Dilleniidae; Ordo: Capparales; Famili: Moringaceae; Genus: Moringa; Spesies: Moringa oleifera Lam (Krisnadi, 2013).

Penelitian fitokimiawi terhadap tanaman Moringa Oleifera ini mengungkapkan terdapat polifenol besar misalnya quercetin glucoside, rutin, kaempferol glycoside, dan chlorogenic acid di dalam tepung Moringa Oleifera melalui analisis HPLC (Johnson, 2005). Kandungan flavonol dan flavones pada daun kelor dengan perhitungan menggunakan kurva standar memberikan hasil sebagai berikut : berdasarkan wet basis (per $100 \mathrm{~g}$ sampel segar), yaitu 1,32 mg luteolin, 95,84 mg quarcetin, dan 20,79 mg kaempferol, sehingga totalnya adalah $117,95 \mathrm{mg}$. Konsentrasi flavonol dan flavone yang diperoleh berdasarkan dry basis (per $100 \mathrm{~g}$ sampel kering) adalah 5,29 mg luteolin, $384,61 \mathrm{mg}$ quarcetin, dan $83,44 \mathrm{mg}$ kaempferol sehingga totalnya adalah 473,33 mg (Rahmat,2009).

Kelor merupakan tanaman yang kaya akan nutrisi seperti halnya zat gizi makro dan mikro, mineral, vitamin. Berbagai bagian dari tanaman Kelor seperti daun, akar, biji, kulit kayu, buah, bunga dan polong dewasa, bertindak sebagai stimulan jantung dan peredaran darah, memiliki antitumor, anti-piretik, anti-epilepsi, antiinflamasi, anti-ulcer, anti-spasmodic, diuretik, anti-hipertensi, menurunkan kolesterol, antioksidan, anti-diabetik, hepatoprotektif, anti-bakteri dan anti-jamur (Krisnadi, 2013)

Tabel 1.1 Komposisi Nutrisi Moringa Oleifera (Gopalakrishnan et al., 2016)

\begin{tabular}{lcc}
\hline Nutrisi & $\begin{array}{c}\text { Daun } \\
\text { segar }\end{array}$ & $\begin{array}{c}\text { Daun } \\
\text { kering }\end{array}$ \\
\hline Calories (cal) & 92 & 329 \\
Protein (g) & 6.7 & 29.4 \\
Fat (g) & 1.7 & 5.2 \\
Carbohydrate (g) & 12.5 & 41.2 \\
Fibre (g) & 0.9 & 12.5 \\
Vitamin B1 (mg) & 0.06 & 2.02 \\
Vitamin B2 (mg) & 0.05 & 21.3 \\
Vitamin B3 (mg) & 0.8 & 7.6 \\
Vitamin C (mg) & 220 & 15.8 \\
Vitamin E (mg) & 448 & 10.8 \\
Calcium (mg) & 440 & 2185 \\
Magnesium (mg) & 42 & 448 \\
Phosphorus (mg) & 70 & 252 \\
Potassium (mg) & 259 & 1236 \\
Copper (mg) & 0.07 & 0.49 \\
Iron (mg) & 0.85 & 25.6 \\
Sulphur (mg) & - & - \\
\hline
\end{tabular}

*Semua hasil dalam 100 gram per materi tanaman

Quercetin merupakan salah satu flavonoid yang berkhasiat sebagai antioksidan. Quercetin adalah senyawa kelompok flavonol terbesar, quercetin dan glikosidanya dalam jumlah sekitar $60-75 \%$ dari flavonoid. Molekuler formula quercetin adalah C15H10O7, ketika flavonol Quercetin bereaksi dengan radikal bebas, Quercetin mendonorkan protonnya dan menjadi senyawa radikal, tapi elektron tidak berpasangan yang dihasilkan didelokasi oleh resonansi, hal ini membuat senyawa Quercetin radikal memiliki energi yang sangat rendah untuk menjadi radikal yang reaktif. Tiga gugus dari struktur Quercetin yang membantu dalam menjaga kestabilan dan bertindak sebagai antioksidan ketika bereaksi dengan radikal bebas antara lain; gugus $\mathrm{O}$-dihidroksil pada cincin $\mathrm{B}$, gugus 4- 
oxo dalam konjugasi dengan alkena 2,3 dan gugus 3- dan 5- hidroksil. Gugus fungsi tersebut dapat mendonorkan elektron kepada cicin yang akan meningkatkan jumlah resonansi dari struktur benzene senyawa Quercetin. Quercetin memperlihatkan aktivitas sebagai antioksidan dengan menurunkan peroksidasi lipid (MDA) dan meningkatkan aktivitas enzim antioksidan pada tikus diabetes melitus yang diinduksi STZ (Adewole et al., 2007).

Moringa oleifera telah terbukti menyembuhkan diabetes melitus baik tipe 1 dan tipe 2. Diabetes tipe 1 merupakan penderita non-produksi insulin, dimana hormon yang mempertahankan kadar glukosa darah yang diperlukan dalam nilai normal. Sedangkan diabetes tipe 2 merupakan penderita yang terkait dengan resistensi insulin. Diabetes tipe 2 mungkin juga dikarenakan disfungsi sel beta yang gagal untuk mempertahankan kadar glukosa, sehingga mengurangi sinyal terhadap insulin, yang mengakibatkan kadar glukosa darah menjadi tinggi. Pada pasien hiperglikemia dengan sel beta mengalami kerusakan, glukosa yang tinggi memasuki mitokondria dan merilis reaktif spesies oksigen. Ketika sel beta memiliki jumlah antioksidan rendah, hal ini akan menyebabkan apoptosis pada sel-sel beta sehingga mengurangi sekresi insulin yang menyebabkan hiperglikemia dan menyebabkan diabetes mellitus tipe- 2 . Flavonoid seperti quersetin dan fenolat telah dikaitkan sebagai antioksidan yang membawa efek pengikatan di ROS. Hal ini dapat dihipotesiskan bahwa flavonoid dalam Moringa dapat membebaskan ROS dari mitokondria, sehingga melindungi sel beta dan mengontrol hiperglikemia (Gopalakrishnan et al., 2016).

Penelitian ini bertujuan untuk mengetahui bahwa pemberian ekstrak daun kelor (Moringa Oleifera) sebagai antioksidan dapat menurunkan kadar MDA pada SOPK dengan resistensi insulin. Tanaman ini merupakan tanaman asli di berbagai negara Asia, berlimpah dan murah sebagai sumber makanan. Dengan demikian, setiap manfaat bagi kesehatan dari tanaman ini akan mencapai sebagian besar penduduk.

\section{METODE PENELITIAN}

Jenis penelitian yang digunakan adalah penelitian eksperimen dengan menggunakan rancangan posttest only control group design dikarenakan untuk memeriksa hasil penelitian harus mengorbankan hewan coba. Pada awal penelitian dilakukan penghomogenan unit eksperimen penelitian.

Unit eksperimen dalam penelitian ini adalah tikus putih (Rattus nervegicus) betina diperoleh dari peternakan Biokimia Fakultas Kedokteran Universitas Airlangga, dengan kriteria sebagai berikut:

1) Kriteria inklusi

- Tikus putih jenis kelamin betina

- Berat badan 100-130 gram

- Berusia 3 bulan

- Sehat, aktivitas dan tingkah laku normal

- Swab vagina

2) Kriteria eksklusi

- Bunting

- Terdapat abnormalitas anatomi yang nampak

3) Kriteria Drop Out

- Bobot tikus menurun

- Mencit tidak mau makan atau mati dalam masa penelitian

Besar sampel minimal yang digunakan berdasarkan rumus umum penelitian eksperimen one tail dengan uji hipotesis pada populasi data kontinyu. Penggunaan sampel masing-masing kelompok sebanyak 8 ekor dianggap sudah memenuhi jumlah replikasi minimal.

Penelitian ini dilakukan di laboratorium Kandang Hewan Coba Fakultas Kedokteran Universitas Airlangga selama 9 minggu. Unit eksperimen dalam penelitian ini adalah tikus Rattus norvegicus stran wistar (Laboratorium Biokimia, Fakultas Kedokteran Universitas Airlangga, Surabaya, Indonesia) betina umur 3 bulan dan mempunyai berat 100-130 gram. Tikus ini juga dipakai dalam penelitian sebagai hewan coba model diabetes (Purwanto et al., 2013).

Sebelum penelitian, dilakukan adaptasi selama 1 minggu, kondisi sehat dengan aktivitas dan tingkah laku normal. Apabila selama adaptasi didapatkan kelainan anatomi yang tampak dan sedang bunting maka unit eksperimen dikeluarkan dari penelitian. Selama penelitian, tikus dipelihara di dalam kandang plastik ukuran 
50x30 cm dengan alas sekam kayu yang diganti setiap 4 hari sekali, pemberian pakan standart dan minum ad libitum yang diletakkan di ruangan berventilasi udara alami dan kondisi pencahayaan alami (Day \& Night). Semua prosedur yang dijelaskan telah sesuai dan disetujui oleh komite etik Fakultas Kedokteran Hewan Universitas Airlangga.

Bahan penelitian ini menggunakan daun kelor (Moringa Oleifera) populer disebut sebagai miracle tree merupakan keluarga Moringaceas yang berasal dari Asia selatan. Tanaman yang tumbuh cepat ini sangat dihargai dan dibudidayakan di daerah tropis dan sub-tropis, dengan nilai gizi tinggi, setiap bagian pohon cocok untuk keperluan nutrisi maupun komersial. Daun pohon ini kaya akan mineral, vitamin dan fitokimia penting lainnya (Sujatha and Patel, 2017). Ekstrak daun kelor (Moringa oleifera) yang dipakai dalam penelitian ini diproses sesuai dengan standar oleh Kelorina, PT. Moringa Indonesia. Ekstrak Moringa oleifera diberikan pada tikus yang mendapatkan perlakuan dengan dosis $250 \mathrm{mg} / \mathrm{kgBB}$ dan $500 \mathrm{mg} / \mathrm{kgBB}$ selama 14 hari dengan menggunakan sonde. Jumlah volume daun kelor (Moringa oleifera) yang diberikan untuk spesies Rat sebesar $0,1-0,2 \mathrm{ml} / 10 \mathrm{~g}$ atau $1-2 \mathrm{ml} / 100 \mathrm{gr}$ (Handout Oral Gavage University of Minnesota driven to discover second edition, 2014). Serbuk daun kelor (Moringa Oleifera) juga dipakai dalam beberapa penelitian untuk mengatahui efektifitasnya pada hiperglikemia kronis dan dyslipidemia (Mbikay, 2012).

Tikus betina putih Wistar strain (Rattus norvegicus) sebanyak 32 sampel dibagi menjadi 4 kelompok secara acak $(\mathrm{n}=8)$. Satu kelompok kontrol normal non-SOPK hanya diberi aquades, sedangkan 3 kelompok yang lain adalah kelompok model SOPK.

Testosteron yang dipakai untuk membuat tikus model SOPK didapatkan dari PT. Wonderindo Pharmatama, Jakarta, Indonesia dengan merk Wonder. Testosteron merupakan hormon yang digunakan untuk pembuatan model Sindroma Ovarium Polikistik (SOPK) pada penelitian ini, hormon ini diberikan kepada tikus $1 \mathrm{kali} / \mathrm{hari}$ selama 28 hari secara intramuskular atau subkutan di paha kiri dengan dosis $1 \mathrm{mg} / 100 \mathrm{grBB}$, volume yang dimasukkan ke setiap tikus adalah $0,1 \quad \mathrm{cc} / 100 \mathrm{grBB}$, diberikan hingga model SOPK-resistensi insulin didapatkan.

Selanjutnya kelompok ke-2 sebagai kontrol SOPK-resistensi insulin hanya diberikan aquades selama 14 hari, kelompok ke-3 dan ke-4 dilanjutkan dengan pemberian ekstrak daun kelor (Moringa oleifera) (250 $\mathrm{mg} / \mathrm{kgBB}$, peroral $)$ dan $(500 \mathrm{mg} / \mathrm{kgBB}$, peroral) selama 14 hari. Sebelum dan sesudah masa penelitian, hewan coba ditimbang untuk mengetahui kenaikan berat badan selama penelitian. Sebelum hewan coba dikorbankan, dipuasakan selama 12 jam lalu diambil darah untuk menganalisis kadar MDA.

Pengambilan spesimen darah dilakukan langsung ke jantung. Caranya dengan menusukan syringe langsung ke jantung dan disedot perlahan. Darah ditampung pada tabung plain tanpa EDTA untuk tujuan pengambilan serumnya kemudian dibiarkan mengendap pada suhu kamar selama 1 jam, selanjutnya dilakukan sentrifugasi dengan kecepatan $4500 \mathrm{rpm}$ selama 10-15 menit untuk mendapatkan serum yang dimaksud. Dari darah yang diambil sebanyak $5 \mathrm{ml}$ dapat diperoleh serum sebanyak 2,5 $\mathrm{ml}$.

Pengukuran kadar MDA menggunakan spesimen serum darah tikus yang kemudian diperiksa menggunakan pereaksi thiobarbituric acid (TBA) dengan melalui reaksi dengan penambahan nukleofilik membentuk senyawa MDA-TBA. Senyawa ini berwarna merah jambu yang dapat diukur intensitasnya dengan menggunakan spektrofotometer pada panjang gelombang $532 \mu \mathrm{m}$. Pengukuran kadar MDA dengan metode simple spectrophotometric ini dilakukan di Laboratorium Biokimia, Fakultas Kedokteran Universitas Airlangga, Surabaya, Indonesia.

Hasil penelitian dianalisis secara statistik menggunakan uji Shapiro-wilk untuk mengetahui normalitas data. Jika data berdistribusi normal dilanjutkan dengan uji statistik one way ANOVA. Apabila salah satu kelompok data tidak homogen atau tidak berdistribusi normal, maka digunakan uji non-parametrik Krukal Wallis. Nilai signifikan pada penelitian ini apabila variabel yang dianalisis memiliki hasil $\mathrm{P}<0,05$. 


\section{HASIL DAN PEMBAHASAN}

Unit eksperimen dalam penelitian ini adalah tikus putih (Rattus nervegicus) betina dengan usia \pm 3 bln dan berat badan 100-130 gram diperoleh dari peternakan Biokimia Fakultas Kedokteran Universitas Airlangga. Sebelum dan sesudah perlakuan dilakukan penimbangan berat badan tikus betina, hasil penimbangan menunjukan rata-rata kenaikan berat badan tertinggi terdapat pada kelompok model SOPK sebesar 74 gram, sedangkan kenaikan berat badan terendah pada kelompok model PCOS dengan perlakuan ekstrak daun kelor (Moringa Oleifera) dengan dosis $500 \mathrm{mg} / \mathrm{KgBB}$ sebesar 55.63 gram (Tabel 3.1).

Tabel 3.1 Distribusi frekuensi berat badan (gram) tikus betina model PCOS sebelum dan sesudah perlakuan

\begin{tabular}{ccccc}
\hline \multirow{2}{*}{ Sampel } & \multicolumn{4}{c}{ Kelompok } \\
\cline { 2 - 5 } & $\mathrm{K} 1$ & $\mathrm{~K} 2$ & $\mathrm{~K} 3$ & $\mathrm{~K} 4$ \\
\hline $\begin{array}{c}\text { Rata-rata } \\
\text { sebelum }\end{array}$ & 115.50 & 121.88 & 112.75 & 119.12 \\
\hline $\begin{array}{c}\text { Rata-rata } \\
\text { sesudah }\end{array}$ & 174.25 & 195.88 & 179.00 & 174.75 \\
\hline $\begin{array}{c}\text { Kenaikan } \\
\text { rata-rata }\end{array}$ & 58.75 & 74 & 66.25 & 55.63 \\
\hline
\end{tabular}

Keterangan:

K1 : kelompok kontrol normal

K2 : kelompok kontrol SOPK-resistensi insulin

K3 : kelompok SOPK-resistensi insulin diberi pengobatan ekstrak daun kelor (Moringa oleifera) $250 \mathrm{mg} / \mathrm{kgBB}$

K4 : kelompok SOPK-resistensi insulin diberi pengobatan ekstrak daun kelor (Moringa oleifera) $500 \mathrm{mg} / \mathrm{kgBB}$

Hiperinsulinemia yang disebabkan oleh resistensi insulin terjadi pada lebih kurang $80 \%$ wanita dengan SOPK dan obesitas sentral, didapatkan juga lebih kurang 30$40 \%$ wanita dengan SOPK yang berbadan kurus. Hal ini disebabkan oleh kelainan pada insulin post-receptor dimana seharusnya yang bekerja fosforilasi tirosin tetapi yang terjadi adalah fosforilasi serin, hal ini memberi efek pada transport glukosa yang masuk ke dalam sel otot ataupun lemak. Pada kondisi resitensi insulin terjadi gangguan sinyal transduksi insulin yang melibatkan dua jalur utama yaitu
Phosphatidilinositol 3 Kinase (PI3K) dan p38 Mitogen Activated Protein Kinase (MAPK) (Kusumastuty and Ratnawati, 2013).

Resistensi insulin secara bermakna dieksaserbasi oleh obesitas dan merupakan faktor utama dalam patogenesis anovulasi dan hiperandrogenism. Kelainan funsgi dari sel beta pankreas juga ditemukan pada SOPK.

Keadaan hiperinsulinemia berakibat pada timbulnya hiperandrogen melalui beberapa mekanisme, pada hati akan berakibat menurunkan produksi SHBG serta penurunan IGFBP-1. Penurunan SHBG akan meningkatkan estradiol serta testosteron bebas (dalam bentuk aktif) dalam darah, sedangkan penurunan IGFBP-1 berakibat meningkatkan bioavalibitas IGF-1 di sel teka, hal ini sangat berperan dalam proses maturasi folikel serta steroidogenesis. Bersama dengan IGF-2 yang dihasilkan di sel teka maka IGF-1 akan merangsang ovarium untuk memproduksi androgen melalui rangsangan pada reseptor IGF-1, hal ini berakibat pada peningkatan androstenedion dan testosteron (Slowey, 2001, Balen et al., 2005).

Hasil pengukuran kadar MDA pada sampel darah tikus betina kelompok kontrol dan kelompok yang diberi perlakuan menggunakan metode spektrofotometri, disajikan dalam bentuk mean dan standar deviasi dapat dilihat pada tabel 3.2.

Tabel 3.2 Pengaruh pemberian ekstrak daun kelor (Moringa oleifera) terhadap kadar MDA tikus betina model SOPK dengan resistensi insulin

\begin{tabular}{ccccc}
\hline Sampel & \multicolumn{4}{c}{ Kelompok } \\
\cline { 2 - 5 } & $\mathrm{K} 1$ & $\mathrm{~K} 2$ & $\mathrm{~K} 3$ & $\mathrm{~K} 4$ \\
\hline Kadar & 1.939 & 5.694 & 3.315 & 1.982 \\
MDA & \pm 0.341 & $\pm 1.464^{\#}$ & $\pm 1.128^{\#}$ & $\pm 0.383^{*}$
\end{tabular}

" signifikan berbeda dari kontrol normal $(\mathrm{p}<0.05)$

*signifikan berbeda dari kontrol SOPKresistensi insulin $(\mathrm{p}<0.05)$

Keterangan:

K1 : kelompok kontrol normal

K2 : kelompok kontrol SOPK-resistensi insulin

K3 : kelompok SOPK-resistensi insulin diberi pengobatan ekstrak daun kelor (Moringa oleifera) $250 \mathrm{mg} / \mathrm{kgBB}$ 
K4 : kelompok SOPK-resistensi insulin diberi pengobatan ekstrak daun kelor (Moringa oleifera) $500 \mathrm{mg} / \mathrm{kgBB}$

Rata-rata kadar MDA kelompok K2 mengalami peningkatan dibanding dengan kelompok K1. Rata-rata kadar MDA pada semua perlakuan (K3 dan $\mathrm{K} 4)$ mengalami peningkatan jika dibandingkan dengan kelompok K1 akan tetapi mengalami penurunan jika dibandingkan kelompok K2. Rata-rata Kadar MDA pada kelompok K4 yang diberi perlakuan pemberian ekstrak daun kelor (moringa oleifera) dengan dosis $500 \mathrm{mg} / \mathrm{kgBB}$ memiliki peningkatan sedikit bahkan hampir memiliki nilai kadar yang sama dengan kelompok kontrol normal (K1).

Hasil uji statistik one way ANOVA yang digunakan dalam mengukur kadar MDA dalam penelitian ini menunjukan nilai $\mathrm{p}<\alpha$ (0.05), artinya bahwa terdapat perbedaan bermakna kadar MDA antar kelompok. Hasil uji Post Hoc Tests menunjukan bahwa tedapat perbedaan yang bermakna antara K1 dan $\mathrm{K} 2$, hal ini menunjukan bahwa pembuatan model SOPK berhasil yang ditandai dengan meningkatnya kadar MDA secara bermakna.

Peningkatan kadar MDA terjadi pada sampel darah tikus betina model SOPK yang mendapatkan injeksi Testosteron Propionat (TP) sebanyak $1 \mathrm{mg} / 100 \mathrm{grBB}$ secara intra muscular selama 28 hari. Peningkatan kadar MDA ini dapat terlihat dari kadar MDA yang lebih tinggi pada kelompok kontrol SOPK-resistensi insulin (K2) dengan jumlah kadar MDA $5.694 \mathrm{nmol} / \mathrm{ml}$ dibandingkan dengan jumlah kadar kelompok kontrol normal yang tidak diberikan perlakuan injeksi testosterone propionat dengan jumlah kadar MDA sebesar $1.939 \mathrm{nmol} / \mathrm{ml}$. Peningkatan Kadar MDA pada tikus betina model SOPK ini menunjukan bahwa terjadi peningkatan oxydative stress pada kelompok tikus yang mendapatkan injeksi testosteron propionat.

Testosteron (androgen) menyebabkan terjadinya peningkatan oxydative stress dengan cara memfasilitasi lipolisis dan pemecahan lemak abdomen yang menyebabkan peningkatan asam lemak bebas (Marshall, 2001). MDA yang dihasilkan selama dekomposisi asam lemak tak jenuh ganda, adalah salah satu produk akhir yang stabil dari peroksidasi lipid yang dapat berfungsi sebagai biomarker yang baik untuk oxydative stress. Penelitian yang dilakukan oleh Sabuncu et al (2001), Zhang et al (2008) dan Kuscu et al (2009) menunjukan tingkat kadar serum MDA yang meningkat secara signifikan pada pasien SOPK dibandingkan dengan non SOPK (Yeon Lee et al., 2010).

Pada penelitian terdahulu, tingkat OS diamati secara signifikan berkorelasi dengan obesitas, resistensi insulin, hiperandrogenimea, dan peradangan kronis. OS dapat menginduksi pelepasan faktorfaktor inflamasi dan respon inflamasi melalui aktivasi nuclear factor- $k B(N F-k B)$, activated protein-1 (AP-1) dan hypoxiainducible factor-1 (HIF-1) (Touyz, 2005) yang selanjutnya bersama inflamasi dapat menginduksi resistensi insulin melalui post insulin receptor signaling pathway, insulin receptor substrate 1-phosphatidyl inositol 3 kinase-protein kinase $B \quad$ (IRSI-PI3K$P K B / A k t)$ pathway. Resistensi insulin mengarah pada kompensasi hiperinsulinemia dan meningkatkan produksi androgen di ovarium. Insulin dan Insulin-Like Growth Factor-1 (IGF-I) inilah yang bertanggung jawab mengganggu ovulasi (Rojas et al., 2014).

Hasil uji Post Hoc Tests menunjukan adanya perbedaan bermakna antara K2 dan K3, K4. Hal ini berarti pemberian ekstrak daun kelor (moringa oleifera) pada tikus betina model SOPK dapat menurunkan kadar MDA dalam darah.

Pemberian ekstrak daun kelor (moringa oleifera) pada tikus betina model SOPK sebagai anti oksidan dalam penelitian ini terbukti dapat menurunkan kadar MDA. Kadar MDA Kelompok K3 yang diberikan ekstrak daun kelor (moringa oleifera) dengan dosis $250 \mathrm{mg} / \mathrm{kgBB}$ rata-rata sebesar $3.315 \mathrm{nmol} / \mathrm{ml}$, hasil ini lebih rendah dari pada kelompok kontrol SOPK-resistensi insulin (K2). Kadar MDA Kelompok K4 yang diberikan ekstrak daun kelor (moringa oleifera) dengan dosis $500 \mathrm{mg} / \mathrm{kgBB}$ mempunyai penurunan yang lebih baik dibanding kalompok $\mathrm{K} 2$ dan $\mathrm{K} 3$ dengan nilai rata-rata $1.982 \mathrm{nmol} / \mathrm{ml}$, hasil ini paling mendekati kontrol normal (K1) yang tidak diberikan perlakuan apapun (1.939 $\mathrm{nmol} / \mathrm{ml}$ ).

Penelitian fitokimiawi terhadap tanaman Moringa oleifera ini 
mengungkapkan terdapat polifenol besar misalnya quercetin glucoside, rutin, kaempferol glycoside, dan chlorogenic acid di dalam tepung Moringa oleifera melalui analisis HPLC (Johnson, 2005). Quercetin merupakan salah satu flavonoid yang berkhasiat sebagai antioksidan. Quercetin adalah senyawa kelompok flavonol terbesar, quercetin dan glikosidanya dalam jumlah sekitar 60-75\% dari flavonoid. Quercetin memperlihatkan aktivitas sebagai antioksidan dengan menurunkan peroksidasi lipid (MDA) dan meningkatkan aktivitas enzim antioksidan pada tikus diabetes melitus yang diinduksi STZ (Adewole et al., 2007). Penelitian yang dilakukan oleh Oparinde dan Atiba (2014) juga menunjukan bahwa pemberian ekstrak daun kelor (Moringa oleifera) pada tikus galur wistar dapat melindunginya dari oxydative stress dengan parameter menurunnya kadar MDA dibandingkan dengan pemberian diet normal (Oparinde and Atiba, 2014).

\section{KESIMPULAN DAN SARAN}

Pemberian ekstrak daun kelor (moringa oleifera) dalam penelitian ini terbukti dapat menurunkan kadar MDA tikus betina model SOPK. Penelitian ini memiliki keterbatasan yaitu parameter yang diperiksa hanya menggunakan kadar MDA sebagai penanda status oksidatif. Penelitian pemberian ekstrak daun kelor (moringa oleifera) sebagai anti oksidan untuk alternatif pilihan pengobatan SOPK perlu dilanjutkan dengan menggunakan parameter yang berbeda sebagai penanda status oksidatif misalnya superoksida dismutase (SOD), dan glutathione peroxidase (GPx).

\section{DAFTAR PUSTAKA}

Adewole, S. O., Caxton-Martins, E. A. \& Ojewole, J. A. 2007. Protective effect of quercetin on the morphology of pancreatic $\beta$-cells of streptozotocintreated diabetic rats. African Journal of Traditional, Complementary and Alternative Medicines, 4, 64-74.

Agarwal, A., Prabakaran, S. A. \& Said, T. M. 2005. Prevention of oxidative stress injury to sperm. Journal of Andrology, 26, 654-660.
Balen, A. H., Conway, G. S., Homburg, R. \& Legro, R. S. 2005. Polycystic ovary syndrome: a guide to clinical management, CRC Press.

Bostancı, S. M., Bayram, M., Sevinç, F. C., Paşaoğlu, H. \& Elbeğ, Ş. 2012. The relationship between biochemical parameters, interleukin-6 and ovarian morphology in polycystic ovary syndrome. Journal of Clinical and Experimental Investigations, 3.

Fahey, J. W. 2005. Moringa oleifera: A Review of the Medical Evidence for Its Nutritional, Therapeutic, and Prophylactic Properties. Part 1. Trees for life Journal, 1.

Fauser, B. C., Tarlatzis, B. C., Rebar, R. W., Legro, R. S., Balen, A. H., Lobo, R., Carmina, E., Chang, J., Yildiz, B. O. \& Laven, J. S. 2012. Consensus on women's health aspects of polycystic ovary syndrome (PCOS): the Amsterdam ESHRE/ASRM-Sponsored 3rd PCOS Consensus Workshop Group. Fertility and sterility, 97, 28-38. e25.

Gopalakrishnan, L., Doriya, K. \& Kumar, D. S. 2016. Moringa oleifera: A review on nutritive importance and its medicinal application. Food Science and Human Wellness, 5, 49-56.

Homburg, R. 2003. The management of infertility associated with polycystic ovary syndrome. Reproductive Biology and Endocrinology, 1, 109.

Homburg, R. 2008. Polycystic ovary syndrome. Best Practice \& Research Clinical Obstetrics \& Gynaecology, 22, 261-274.

Jackson, M. J. 2005. Reactive oxygen species and redox-regulation of skeletal muscle adaptations to exercise. Philosophical Transactions of the Royal Society B: Biological Sciences, 360, 2285-2291.

Johnson, B. 2005. Clinical perspectives on the health effects of Moringa oleifera: A promising adjunct for balanced nutrition and better health. KOS health publications.

Kusumastuty, I. \& Ratnawati, R. 2013. Epigallocatechin Gallate Green Tea GMB4 Clon Prevent Insulin Resistance due to High Fat Diet in Rat. Jurnal Kedokteran Brawijaya, 26, 63-68.

Marshall, K. 2001. Polycystic ovary syndrome: clinical considerations. Alternative Medicine Review, 6, 272-272.

Mbikay, M. 2012. Therapeutic potential of Moringa oleifera leaves in chronic hyperglycemia and dyslipidemia: a review. Frontiers in pharmacology, 3. 
Mukherjee, S. \& Maitra, A. 2010. Molecular \& genetic factors contributing to insulin resistance in polycystic ovary syndrome.

Oparinde, D. P. \& Atiba, A. S. 2014. Moringa oleifera Leaf Prevents Oxidative Stress in Wistar Rats.

Powers, S. K. \& Jackson, M. J. 2008. Exerciseinduced oxidative stress: cellular mechanisms and impact on muscle force production. Physiological reviews, 88, 1243-1276.

Purwanto, B., Sudiana, I. K., Herawati, L. \& Aksono, B. 2013. MUSCLE GLUCOSE TRANSPORTER 1 (GLUT-1) EXPRESSION IN DIABETIC RAT MODELS. Folia Medica Indonesiana, 49, 21-25.

Rojas, J., Chávez, M., Olivar, L., Rojas, M., Morillo, J., Mejías, J., Calvo, M. \& Bermúdez, V. 2014. Polycystic ovary syndrome, insulin resistance, and obesity: navigating the pathophysiologic labyrinth. International journal of reproductive medicine, 2014.

Roloff, A., Korn, S. \& Gillner, S. 2009. The climate-species-matrix to select tree species for urban habitats considering climate change. Urban Forestry \& Urban Greening, 8, 295-308.

Rusnasari, V. D. 2005. HUBUNGAN RESISTENSI INSULIN (HOMA-IR) DENGAN OBESITAS DAN PERUBAHAN HORMON ANDROGEN PADA PENDERITA SINDROMA OVARIUM POLIKISTIK. Program Pasca Sarjana Universitas Diponegoro.

Sikka, S. C., Rajasekaran, M. \& Hellstrom, W. J. 1995. Role of oxidative stress and antioxidants in male infertility. Journal of andrology, 16, 464-468.

Slowey, M. J. 2001. Polycystic ovary syndrome: new perspective on an old problem. Southern medical journal, 94, 190-196.

Sujatha, B. \& Patel, P. 2017. Moringa OleiferaNature's Gold. Imperial Journal of Interdisciplinary Research, 3.

Tan, H. 2011. Perbandingan Efektifitas dan Efek Samping Pemakaian Metformin XR dan Metformin IR dalam Pengobatan PCOS yang Resisten terhadap Clomiphene Citrate.

Teede, H. J., Misso, M. L., Deeks, A. A., Moran, L. J., Stuckey, B., Wong, J., Norman, R. J., Costello, M. F. \& Guideline, D. G. 2011. Assessment and management of polycystic ovary syndrome: summary of an evidence-based guideline. The

Medical Journal of Australia, 195, S65.
Touyz, R. M. 2005. Molecular and cellular mechanisms in vascular injury in hypertension: role of angiotensin IIeditorial review. Current opinion in nephrology and hypertension, 14, 125131.

Valkenburg, O., Steegers-Theunissen, R. P., Smedts, H. P., Dallinga-Thie, G. M., Fauser, B. C., Westerveld, E. H. \& Laven, J. S. 2008. A more atherogenic serum lipoprotein profile is present in women with polycystic ovary syndrome: a case-control study. The Journal Of Clinical Endocrinology \& Metabolism, 93, 470-476.

Winarsi, H. 2005. Antioksidan Alami dan Radikal, Kanisius.

Yeon Lee, J., Baw, C.-K., Gupta, S., Aziz, N. \& Agarwal, A. 2010. Role of oxidative stress in polycystic ovary syndrome. Current Women's Health Reviews, 6 , 96-107.

Ziech, D., Franco, R., Pappa, A. \& Panayiotidis, M. I. 2011. Reactive Oxygen Species (ROS) - Induced genetic and epigenetic alterations in human carcinogenesis. Mutation Research/Fundamental and Molecular Mechanisms of Mutagenesis, 711, 167-173.

Zuo, T., Zhu, M. \& Xu, W. 2015. Roles of oxidative stress in polycystic ovary syndrome and cancers. Oxidative medicine and cellular longevity, 2016. 